\title{
Appendix: Language data
}

The appendix presents a summary of data on the cross-linguistic distribution of degree expressions which were discussed in chapter 2.4.2. For all languages, the data are organized as follows: first the adverbial uses of degree expression (degree and extent gradation) are listed, then adadjectival uses (gradation of positive and comparative forms) follows and finally adnominal uses (quantity expressions with mass and count nouns) can be found. If there is nothing special to say on the data, no further comments are added. The relevant discussion of the data can be found in chapter 2.4.2. A note on the translation of degree expressions: if a language distinguishes between a verbal degree and extent intensifier, I gloss the degree intensifier as very throughout all its uses and the extent intensifier as much. If a language has a general 'de-intensifier', I gloss it as a lot.

The appendix lists all the data not presented in chapter 2.4.2 except the Finnish data, which were taken from Karttunen (1975). ${ }^{4}$ A short note on the sources of the other data: I collected or at least checked all language data with native speaker consultants, if there is no other source indicated. See the introduction for the list of informants.

Arabian (Morrocan) (Semitic < Afro-Asiatic)

(11) adverbial

a. Axa:fa al-adad-u al-walad-a käir-an. frightened DET-lion-NOM DET-boy-ACC a lot-ADV 'The lion frightened the loy a lot.'

Karttunen does not discuss the use of Finnish hyvin 'very' with the positive form of adjectives. An example of this missing type of data is the following:

i. Talo on hyvin suuri.

house is very tall

'The house is very tall.' 
Appendix: Language data

b. Al-walad-u na:ma katir-an fi l-lajlat- $i$ DET-boy-NOM slept a lot-ADV at DET-night-GEN $l$-mad iyat-i. DET-last-GEN

'The boy slept a lot last night.'

c. ðahaba käir-an ila s-si:nima. went a lot-ADV to DET-cinema 'He went to the cinema a lot.'

(12) adadjectival
a. Al-walad-u $t^{\mathrm{f}}$ awi:l-um dzidd-an. DET-boy-NOM tall-NOM very-ADV 'The boy is very tall.'

b. Al-walad-u at ${ }^{\mathrm{\complement}}$ wal-u katir-an min DET-boy-NOM tall.COMP-NOM a lot-ADV from axi-h-i. brother-POSS.3SG-GEN

'The boy is much taller than his brother.'

(13) adnominal
a. Akala l-kaOir-a mina l-mawz-i. ate DET-a lot-ACC from DET-banana.PL-GEN 'He ate many bananas.'
b. Akala l-käir-a mina $\int-\int u r b a t-i$. ate DET-a lot-ACC from DET-soup.SG-GEN 'He ate a lot of soup.'

Bulgarian (Slavic < Indo-European)

(14) adverbial
a. Momče-to običa mnogo majka si. boy-DEF loves a lot mother poss 'The boy loves his mother very much.'

b. Toj hodi mnogo na kino.

he goes a lot PREP cinema 'He goes to the cinema a lot.' 

C. Snošti spah mnogo.
last.night sleep.AOR a lot
'Last night, I slept a lot.' (= long duration)

(15) adadjectival
a. Momče-to e mnogo visoko.
boy-DET AUX a lot tall
'The boy is very tall.'
b. Momče-to e mnogo po-visoko ot prijatel-ja si. boy-DEF AUX a lot COMP-tall PREP friend-DEF POSS 'The boy is much taller than his friend.'

(16) adnominal
a. Toj ima mnogo knigi.
he has a lot book.PL
'He has many books.'
b. $V$ kofa-ta ima mnogo voda.
PREP bucket-DEF has a lot water
'There is a lot of water in the bucket.'

\section{Croatian (Slavic $<$ Indo-European)}

(17) adverbial
a. Pas je dječaka jako prestrašio.
$\mathrm{dog}$ is boy.Acc very frightened
'The dog frightened the boy a lot.'
b. Dječak mnogo ide u kino.
boy much goes PREP cinema
'The boy goes to the cinema a lot.'
c. Dječak je mnogo spavao prošle noći. boy is much slept last night 'The boy slept a lot last night.'

(18) adadjectival
a. Dječak je jako visko. boy is very tall
'The boy is very tall.' 
Appendix: Language data

b. Dječak je mnogo viši svoje sestre.

boy is much tall.cOMP REFL sister

'The boy is much taller than his sister.'

(19) adnominal
a. Pojeo je mnogo jabuka. eaten is much apple 'He ate many apples.'
b. Pojeo je mnogo juhe. eaten is much soup 'He ate much soup.'

Dutch (Germanic < Indo-European)

(20) adverbial

a. De jongen houdt erg/veel van zijn moeder. the boy loves very/much PART his mother 'The boy loves his mother very much.'

b. Hij gaat veel naar de cinema.

he goes much to the cinema 'He goes to the cinema a lot.'

c. Voorbije nacht hab ik veel geslapen. last night have I much slept 'Last night, I slept a lot.'

(21) adadjectival

a. De jongen is erg/zeer groot. the boy is very/very tall 'The boy is very tall.'

b. De jongen is veel grot-er dan zijn vriend. the boy is much tall-comp than his friend 'The boy is much taller than his friend.'

(22) adnominal
a. Hij bezit veel boeken.
he owns much books
'He owns many books.' 
b. Er is veel water in de emmer.

it is much water in the bucket

'There is a lot of water in the bucket.'

\section{Estonian (Finno-Ugric)}

(23) adverbial
a. Poiss väga armastab oma ema.
boy very loves POSS.SG mother.GEN
'The boy loves his mother very much.'
b. Ta käib palju Kino-sse.
he goes much cinema-ILL.SG
'He goes to the cinema 1 lot.'
c. Viima-sel öö-sel olen ma plaju maga-nud.
last-ADE.SG night-ADE.SG be.1sG I much sleep-PST.PRF 'Last night, I slept a lot.'

(24) adadjectival
a. Poiss on väga suur.
boy be.3sg very tall
'The boy is very tall.'
b. Poiss on palju suur-em kui tema sõber. boy be.3sg much tall-comp.sG than 3sG.GEN friend 'The boy is much taller than his friend.'

(25) adnominal
a. Tal on palju raamatu-id.
3SG.ADE be.3SG much book-PAR.PL
'He owns many books.'
b. Ämbr-is on palju vett. bucket-INE.SG 3SG much water.PAR.SG 'There is a lot of water in the bucket.'


Appendix: Language data

Georgian (Kartvelian)

(26) adverbial
a. bič's žalian uq'vars tavis- $i$ deda- $\emptyset$. 'The boy loves his mother very much.' boy-DAT very loves his-NOM mother-NOM
b. bič's c'uxel bevr-i edzina. boy-DAT last.night much-NOM slepp.AOR 'The boy slept a lot last night.'
c. bič'-i bevr-s dadis. boy-NOM much-DAT goes 'The boy goes a lot.' (= 'he often walks')

(27) adadjectival
a. bič’ $i \quad \check{z}$ alian didi-a. boy-NOM very be-tall 'The boy is very tall.'
b. bič'-i tavis megobar-ze bevr-da didi-a. boy-NOM is friend-over much-ADV be-tall 'The boy is much taller than his friend.'

(28) adnominal
a. bič-ma sup-i bevr-i čama. boy-ERG soup-NOM much-NOM eat.aor 'The boy ate a lot of soup.'
b. man bevr-i vašl-i čama.
3sG.ERG much-NOM apple-NOM eat.AOR 'He ate many apples.'

Hebrew (Semitic < Afro-Asiatic)

(29) adverbial
a. Ha-Parje meiod hifxid et ha-jeled. DEF-lion very frightened ACC DEF-boy 'The lion frightened the boy.'

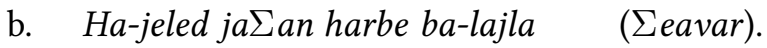 DEF-boy slept much in.DEF-night (previous) 'The boy slept a lot last night.'



c. Hu halax harbe ka-kolnoa.
he went much to.DEF-cinema
'He went to the cinema a lot.'

(30) adadjectival
a. Ha-jeled meiod gavoa.
THE-boy very tall
'The boy is very tall.'

b. Ha-jeled harbe joter gavoa me-axiv.

DEF-boy much moore tall than-brother.POss.3sG.MASC

'The boy is much taller than his brother.'

(31) adnominal
a. Hu axal harbe bananot.
he ate much bananas
'He ate many bananas.'
b. Hu axal harbe marak.
he ate much soup
'He ate a lot of soup.'

For more data see Glinert (1989, chapter 20).

Italian (Romance < Indo-European)

(32) adverbial
a. Mi diverto molto.
myself amuse a lot
'I amuse myself very much.'
b. Vado molto al cinema.
go a lot to.the cinema
'I go to the cinema a lot.'
c. Molto lavorato.
a lot worked
'I worked a lot.' (= long duration or frequency)

(33) adadjectival
a. E'una torre molto alta. is one tower a lot high
'This is a very high tower.' 
Appendix: Language data

b. Sei molto più alto di Luigi.

are a lot more tall than Luigi

'You are much taller than Luigi.'

(34) adnominal
a. molti libri
a lot books
'many books'
b. molta acqua
a lot water
'a lot of water'

Japanese (isolate)

(35) adverbial

a. Sono shōnen wa shinchou ga totemo nobi-ta.

DEM boy suB body.size NOM very grow-PST

'The boy has grown a lot.'

b. Sakuya, watashi wa takusan suimin o to-tta. last.night I suB much sleep Acc take-PST

'I slept a lot last night.' (= long duration)

c. Saikin no kodomo takusan telebi o mi-ru.

newly GEN child much TV ACC watch-PRES

'Today's children watch TV a lot.' (= often)

(36) adadjectival

a. Sono shōnen wa totemo ookii.

DEM boy suB very tall

'The boy is very tall.'

b. Sono shōnen wa kare no tomodachi yori totemo ookii.

DEM boy SUB 3sG.MASC GEN friend than very tall

'The boy is much taller than his friend.'

(37) adnominal

a. Baketto ni wa takusan no mizu ga haitteiru.

bucket in TOP much GEN water NOM enter.PRES

'There is a lot of water in the bucket.' 
b. Kare wa takusan no hon o mo-tte 3SG.MASC SUB much GEN book ACC have-CON i-ru.

be.there-PRES

'He has many books.'

Khalka Mongolian (Mongolia < Altaic)

(38) adverbial
a. Ene xüü eej-iig-ee
DEM boy mother-ACC-REFL.POSS a lot miss-PF 'The boy misses his mother a lot.' ix sana-san.
b. Ter kino-(n)d ix yav-dag. 3sg kino-DAT a lot go-HAB 'He goes to the cinema a lot.'
c. Óčigdör šönö bi ix unt-san. yesterday night 1SG a lot sleep-PF 'Last night, I slept a lot.' (= long duration)

(39) adadjectival
a. Ene xüü ix öndör/tom. DEM boy a lot high/tall 'The boy is very tall.'
b. Ene xü̈ naiz-aas-aa iluu ix öndör/tom. DEM boy friend-ABS-REFL.POSS more a lot high/tall 'The boy is much taller than his friend.'

(40) adnominal
a. Xuvin-d ix us bai-na.
bucket-DAT a lot water be-NPST
'There is a lot of water in the bucket.'
b. Ter olon nom-toi.
3sg much book-com
'He owns many books.'


Kikuyu (Bantu <Niger-Congo)

(41) adverbial
a. Ka-hee
$k-\varepsilon-\varepsilon n e-\varepsilon \varepsilon t \varepsilon$
nyina
mons.

NC12-boy NC12-PRs-love-ASP his.brother a lot

'The boy loves his mother very much.'

b. Ka-hee ka-ra-ko-ire mono hwae.

NC12-boy NC12-PST-sleep-ASP a lot last.night

'The boy slept a lot last night.'
c. Ne a-a-thi-aga mono thinema.
AM 3sG-PST-go-HAB a lot cinema
'He went to the cinema a lot.'

(42) adadjectival
a. Ka-hee ne ka-raihu monэ. Nc12-boy CoP Nc12-be.tall a lot 'The boy is very tall.'
b. Ka-hee ne ka-raihu makeria ma mo-oro wa NC12-boy COP NC12-be.tall excessive of CL1-son of nyina.
his.brother
'The boy is much taller than his brother.'

It is not clear whether raihu is an adjective or a verb; it is translated as a verb but requires the copula, much like predicative adjectives in other languages, e.g. the Bantu language Swahili.

(43) adnominal
a. A-a-re-ire ma-rigo ma-inge. 3SG-PST-eat-ASP NC6-banana Nc6-much 'He ate many bananas.'
b. A-a-nyu-ire thußo mo-inge. 3SG-PST-drink-ASP soup[NC9] NC9-much 'He ate a lot of soup.'


Korean (isolate)

(44) adverbial
a. $\quad k u$ sonyen-un emeni-lul acwu salangha-nta. DEM boy-TOP mother-ACC very love-DEC 'The boy loves his mother very much.'
b. $\quad k u$ sonyen-un manhi ca-ss-ta. DEM boy-TOP much sleep-PST-DEC 'The boy slept a lot.'
c. ku-nun yenghwakwan-ey manhi ka-nta. he-TOP cinema-to much go-DEC 'He goes to the cinema a lot.'

(45) adadjectival
a. ku namca-nun acwu khu-ta. DEM man-TOP very tall-DEC 'The man is very tall.'
b. ku sonyen-un ne-uy hyeng-pota manhi khu-ta. DEM boy-TOP you-GEN older.brother-than much tall-DEC 'The boy is much taller than his older brother.'

(46) adnominal
a. ku-nun sakwa-lul manhi mek-ess-ta.
he-TOP apple-ACC much eat-PST-DEC
'He ate many apples.'
b. ku-nun kwuk-ul manhi mek-ess-ta. he-TOP soup-ACC much eat-PST-DEC 'He ate a lot of soup.'

\section{Mandarin Chinese (Sinitic $<$ Sino-Tibetian)}

(47) adverbial
a. nà gè nǔhái hěn xĭhūan nà tiá gǒu. DEM CLA girl very like DEM CLA dog 'The girl likes the dog very much.'
b. tā qiù diàny̌̀ngyùan hěn dūo. 3sg go cinema much '(S)he goes to the cinema a lot.'


Appendix: Language data

c. tā zuotian shui le hěn dūo.

3SG yesterday sleep PF much

'Yesterday, he slept a lot.' (= long duration)

(48) adadjectival

a. nà gè nánhái hěn gāo.

DEM CLA boy very tall

'The boy is very tall.'

b. nà gè nánhái b̌ tā péngyou gāo hěn dūo.

DEM CLA boy COMP 3SG friend tall much

'The boy is much taller than his friend.'

(49) adnominal

a. nà gè nánrén yǒu hěn dūo shū.

DEM CLA man have much book

'The man has many books.'

b. tā lì shǔi hěn dūo.

3SG CLA water much

'There is a lot of water.'

Nepali (Indo-Aryan <Indo-European)

(50) adverbial

a. Tyo singha-le tyo keto-lāi dherai darāyo.

that lion-ERG that boy-Acc a lot frightened

'The lion frightened the boy.'

b. Tyo keto hijo rati dherai sutyo.

that boy last night a lot slept

'The boy slept a lot last night.'

c. $U$ cinema dherai jānthyo.

3SG.MAsc cinema a lot went

'He went to the cinema a lot.'

(51) adadjectival

a. Tyo keto dherai aglo chha.

that boy a lot tall is

'The boy is very tall.' 
b. Tyo keto usko bhāi bhandā dherai aglo chaa. that boy his younger.brother than a lot tall is 'The boy is much taller than his younger brother.'

(52) adnominal
a. U-sle dherai syāu-haru khāyo.
3sG.MASC-ERG a lot apple-PL ate
'He ate many apples.'
b. U-sle dherai jhol khāyo.
3sG.MASC-ERG a lot soup ate
'He ate a lot of soup.'

Polish (Slavic < Indo-European)

(53) adverbial
a. Ta dziewczyna bardzo lubi tego psa. DEM girl very likes DEM dog 'The girl likes the dog very much.'
b. Ona chodzi dużo do kin-a. she goes much PREP cinema-GEN 'She goes to the cinema a lot.'
c. On duzo spat. he much slept 'He slept a lot.' (= long duration or frequency)

(54) adadjectival
a. Ten chtopiec jest bardzo wysoki.
DEM boy is very tall
'The boy is very tall.'
b. Ten chłopiec jest dużo wyższy niż swój przyjaciel. DEM boy is much tall.comp than his friend 'The boy is much taller than his friend.'

(55) adnominal
a. Ten mężczyzna ma dużo książek.
DEM man has much books
'The man has many books.' 
Appendix: Language data

b. $\quad W$ jeziorze jest dużo wody.

PREP sea is much water

'There is a lot of water in the sea.'

Romanian (Romance $<$ Indo-European)

(56) adverbial

a. Bǎiat-ul o iubesšte mult pe mama sa.

boy-DEF she.Acc loves a lot PREP mother his

'The boy loves his mother very much.'

b. Noapte-a trecută am dormit mult.

night-DEF passed have slept a lot

'Last night, I slept a lot.'

c. El merge mult cu bicileta.

he goes a lot with bike

'He rides his bike a lot.'

(57) adadjectival

a. Băiat-ul este foarte înalt.

boy-DEF is very tall

'The boy is very tall.'

b. Bǎiat-ul este mult mai înalt decât prient-ul său. boy-DEF is a lot more tall than friend-DEF his 'The boy is much taller than his friend.'

(58) adnominal
a. Are mult cărţi.
has a lot books
'He has many books.'
b. Este multǎ apă în gǎleată.
is much water in bucket
'There is a lot of water in the bucket.' 
Spanish (Romance $<$ Indo-European)

(59) adverbial
a. Me gusta mucho el libro. me like a lot the book 'I like the book a lot.'
b. Juan va mucho en tren. Juan goes a lot in train 'Juan takes the train a lot.'
c. Es esa oficina te hacen esperar mucho. in that office CL.you make wait a lot 'In that office they make you wait for a long time.'

(60) adadjectival (Moriena \& Genschow, 2005, 537)
a. El camino fue muy pesado.
the track was very hard
'The track was very difficult.'
b. Ella es mucho menos estricta de lo que parece. she is a lot less severe PREP it than seems 'She is much less severe than she seems.'

(61) adnominal
a. mucha leche
a lot milk 'much milk'
b. muchos amigos
a lot friends 'many friends'

\section{Swahili (Bantu $<$ Niger-Congo)}

(62) adverbial
a. Simba a-li-m-shtua m-vulana sana lion[NC1] NC1-PST-3SG.OBJ-frighten NC1-boy very 'The lion frightened the boy a lot.'
b. M-vulana a-li-lala sana jana usiku. NC1-boy 3sG-PST-sleep very yesterday night 'Last night, the boy slept much a lot.'


Appendix: Language data

c. A-li-kuwa yu-a-enda sana kwa sinema.

3SG-PST-COP 3SG-PST-go very to cinema

'He went to the cinema a lot.'

(63) adadjectival

a. M-vulana ni m-refu sana.

NC1-boy cop NC1-tall very

'The boy is very tall.'

b. M-vulana ni m-refu sana ku-m-liko ndugu NC1-boy COP NC1-tall very INF-3SG.OBJ-surpassing brother yake.

his

'The boy is much taller than his brother.'

(64) adnominal

a. A-li-kula ndizi ny-ingi.

3SG-PST-eat bananas NC9/10-much

'He ate many bananas.'

b. A-li-kunyua supu ny-ingi.

3SG-PST-drink soup[CL9] NC9-much

'He ate much soup.'

Swedish (Germanic < Indo-European)

Swedish uses mycket in all contexts but a different intensifier is used with the positive form of adjectives in negated contexts. In this context, Swedish uses inte särskilt 'not very' (68a), whereas in the other contexts - if negated - inte mycket 'not much' is used (68b). The same is true for Danish (Allan et al., 1995, 316f.), Finnish and Latvian (Bernard Wälichli p.c.).

Unfortunately, I do not have data for the durative subtype of extent gradation.

(65) adverbial

a. Eleverna tyckte mycket om henne.

pupils.DET liked a lot of her

'The pupils liked her a lot.' (Holmes \& Hinchliff, 2008, 145) 
b. Han sjöng mycket på den tiden.

he sang a lot in this time

'He sang a lot in those days.' (Holmes \& Hinchliff, 2008, 197)

(66) adadjectival

a. Han var mycket lång.

he was a lot tall

'He was very tall.'

b. Han var mycket längre än si bror.

he was a lot tall.comp than his brother

'He was much taller than his brother.'

(67) adnominal

a. mycket mygg $i$ fjällen

a lot mosquitoes in mountains

'a lot of mosquitoes in the mountains' (Holmes \& Hinchliff, 2008, 44)

b. mycket vatten

a lot water

'a lot of water'

(68) Negation (Holmes \& Hinchliff, 2008, 146)

a. Han är inte särskilt rik.

he is not very rich

'He is not very rich.'

b. Han är inte mycket rikare än sin bror.

he is not a lot richer than his brother

'He is not much richer than his brother.'

Tatar (Turkic <Altaic)

(69) adverbial

a. kyč $k$ bik kurk-yt-ty marat-ny

dog very fear-CAUS-PST.3sg Marat-ACC

'The dog frightened Marat a lot.'

b. marat küp jer-i kino-ga.

Marat much go-IMPF cinema-DAT

'Marat goes to the cinema a lot.' 
Appendix: Language data

c. marat küp jyklady kicäge ten-ne.

Marat much sleep-PST last night-ACC

'Marat slept a lot last night.'

(70) adadjectival
a. marat bik bijek.
Marat very tall
'Marat is very tall.'
b. marat küp-kä alsu-dan bijek-räk.
Marat much-DAT Alsu-ABL tall-comP
'Marat is much taller than Alsu.'

(71) adnominal
a. marat küp alma aša-dy.
Marat much apple eat-PST
'Marat ate many apples.'
b. marat küp šurba aša-dy.
Marat much soup eat-PST
'Marat ate much soup.'

Turkish (Turkic < Altaic)

(72) adverbial (Güven, 2010, 3)

a. Sibel pembe elbisesini çok beğeniyor.

Sibel pink dress.Acc a lot likes

'Sibel likes her pink dress a lot.'

b. Sibel o odada çok oynuyor.

Sibel that room.Loc a lot plays

'Sibel plays in that room a lot.'

(73) adadjectival
a. Brezilya çok büyüktür.
Brasil a lot large.cop
'Brasil is very large.' (Güven, 2010, 3)
b. Ferrari Ford'dan çok daha hitlı.
Ferrari Ford.ABL a lot more fast
'Ferrari is faster than Ford.' (Mine Güven, p.c.) 
(74) adnominal (Güven, 2010, 5)
a. Çok kitap okurum.
a lot book read
'I read a lot of books.'
b. Çok su içerim.
a lot water drink
'I drink a lot of water.' 
